\title{
Commercializing biomedical science in a rapidly changing "triple-helix" nexus: The experience of the National University of Singapore
}

\author{
Poh-Kam Wong
}

Published online: 29 December 2006

(C) Springer Science+Business Media, LLC 2006

\begin{abstract}
Since the late 1990s, the Singapore government had embarked on a significant push to develop the city-state into a major life-science $R \& D$ and industrial cluster in Asia. Although a major focus of this new thrust involves attracting leading life science companies overseas to establish operations in Singapore and developing new public life science research institutions to attract overseas life science research talents (Finegold, Wong, and Cheah (2004)), the local universities are expected to play an important role as well. In particular, the National University of Singapore (NUS), the leading university in Singapore, has also started to pursue major strategic change to become more "entrepreneurial", and identified life science as a major focus for technology commercialization as well. Adapting the "Triple-Helix" framework of Etzkowitz, Webster, Gebhardt, \& Terra (2000), this paper examines the significant changes in the university-government-industry "Triple-Helix" nexus for life science in Singapore, and their consequent impact on life science commercialization at NUS. Implications for universities in other late-comer countries seeking to catch up in the global biotech race are discussed.
\end{abstract}

Keywords University technology commercialization · Innovation policy · Life science $\cdot$ Singapore

JEL Classifications $\mathrm{O} 31 \cdot \mathrm{O} 32 \cdot \mathrm{O} 53$

\section{Introduction}

There is by now a vast literature on the genesis and growth of biotechnology clusters in the world (see e.g. Cooke 2003, 2004). Notwithstanding some regional variations, the general consensus appears to be the critical new knowledge generation role of

P.-K. Wong $(\bowtie)$

NUS Entrepreneurship Centre, National University of Singapore,

Singapore, Singapore

e-mail: pohkam@nus.edu.sg 
universities and public research institutes in the emergence and sustained growth of every major biotechnology cluster in the world. For example, Feldman and Francis (2003) showed how public funding of NIH in the Capitol region helped cement the region as the leading biomedical hub in the US, while Casper (2003) similarly argued for the crucial role of Cambridge University in the growth of the Cambridge area as a leading life science hub in Europe. As pointed out by Owens-Smith, Riccaboni, Pammolli, and Powell (2005) and Prevezer (2001), however, significant differences exist in terms of university organization and governance between the US and Europe, resulting in distinctive differences in the role of universities in the commercialization of life sciences in the US and Europe. Although no comprehensive studies have been conducted in the Asian context, preliminary evidence emerging in the literature (see e.g. Allen and Wong (2003)) suggests that Asian university technology commercialization practices appear to differ from the US model as well.

This paper examines the changing role of university in the national strategy to accelerate the development of Singapore as a regional hub for commercialization of life sciences. The paper focuses in particular on the National University of Singapore, the leading and largest comprehensive public university in Singapore. The government of Singapore is of course not exceptional in terms of its strategic targeting of the life science industry as a major economic development engine; the government of many other countries, not only relatively advanced ones but also newly industrialized economies and developing ones, have espoused a vision to build up indigenous biomedical industry capabilities. What probably makes the Singapore case of particular interest is the scale and intensity of the government effort. Moreover, this strategic move is taken from an initial position that is arguably further away from the biomedical technology frontier than were many other advanced OECD countries pursuing similar goals. The experience of Singapore is thus of relevant interest to study how the mission and governance of local universities in late-comer economies can be reformed to enable such economies to achieve a faster "catch-up" in the global biotech race.

\section{Theoretical framework: adaptation of the nexus of Triple-Helix in a small open economy}

As argued by Etzkowitz et al. (2000), universities around the world increasingly operate within a Triple-Helix nexus involving interaction with government institutions and private industries. In the context of life science, the nexus is characterized by a number of special characteristics, as summarized in Table 1. Notwithstanding some

Table 1 Key actors in the Triple-Helix nexus of life science

\begin{tabular}{ll}
\hline Private Industry & - Large global pharmaceutical MNCs \\
& - Dedicated biotech firms (DBFs) \\
& - Venture capital firms \\
Government & Public Research Institute \\
& - Public Hospitals \\
& - Regulatory Institutions (Drug approval (equivalence of FDA), \\
& healthcare policy setting agencies, etc.) \\
Universities & - Teaching faculty/Research Labs \\
& - Technology licensing/commercialization arms
\end{tabular}


regional variations (Cooke, 2003, 2004), literature on the emergence and growth of leading life science industrial clusters in advanced countries suggest that they all share the core elements identified in Table 1: (a) the presence of cutting edge basic biomedical research by universities and public research institutes; (b) the emergence of entrepreneurial dedicated biotechnology firms (DBFs) seeking to commercialize certain promising results from the basic research; (c) the availability of seed funding by specialized venture capital that facilitates the formation of such DBFs; and (d) the provision of more sizable follow-on funding by large pharmaceutical firms to the DBFs in exchange for licensing deals that provide them with the downstream marketing and distribution rights. In most clusters, the presence of advanced hospitals (often in close proximity or related to the universities or research institutes) also provided significant lead-user feedbacks and testbeds of new medical technologies.

As argued by Cooke (2003), the science-driven nature of the biomedical industry suggests a higher degree of governmental role in the Triple-Helix nexus compared to other industries where "Porterian" market competitive forces may exert greater influence. However, in the context of small, open economies, especially late-industrializing economies like Singapore, the potential for greater governmental role is offset by the significantly higher degree of linkages to foreign actors. Although even advanced life science clusters in the world have a significant amount of extra regional and international linkages due to the global nature of life science knowledge production (Cooke, 2004), the degree of external linkages are expected to be significantly higher for any life science clusters to be established in small open economies like Singapore. In particular, from a public policy perspective, a strategic issue is how much a small open economy can afford to develop and nurture her own indigenous capabilities versus "borrowing" or "importing" the relevant capabilities from outside. To the extent that public policy puts greater weight on leveraging foreign linkages, it may entail significant changes to the structure of the traditional Triple-Helix nexus. This in turn puts greater pressure on the capabilities of the local universities to adapt their traditional governance and organization to assimilate or otherwise accommodate an increasingly greater degree of foreign elements in their own organization as well as in their nexus of external relationships.

Using the above framework, and building upon my earlier work on life-science cluster development in Singapore (Finegold et al., 2004) and national innovation system development more generally (Wong 2001, 2005), I first examine the key changes in the two key external sectors in the Triple-Helix nexus to which the National University of Singapore (NUS) is linked, before analyzing how the university responds to these external changes through instituting internal changes. I will then examine the impact such external and internal changes have on the performance of NUS' life science commercialization.

\section{Changes to the external industry and public policy contexts for life science commercialization}

\subsection{Overview of Singapore's economic development strategies}

Having achieved remarkable economic growth in the four decades after political independence in 1965, the city-state of Singapore entered the 21 st century with a relatively high level of income/capita, but growing recognition of the need to sustain 
future growth through innovation. As highlighted by Wong (2001, 2005), for much of its history of rapid economic growth, Singapore had relied on a strategy of attracting DFI from global MNCs and leveraging them to exploit technologies and know-how developed elsewhere. However, as the city state's costs increasingly approach those of leading cities in the advanced economies, and as global competition for DFI continues to intensify particularly with the opening up of major economies in Asia like China and India with large domestic markets and abundant supply of skills, its only recourse to stay competitive is to become more innovative, i.e. not just by being efficient in "using" technologies and knowledge produced elsewhere, but by "creating" (commercializing) its own intellectual capital as well.

The global MNC-leveraging strategy has served Singapore well in the past, by making Singapore a leading information technology and electronics manufacturing and services hub in the world (Wong, 2002). Although on a smaller scale and started later, the same leveraging strategy appears to have worked as well in terms of developing Singapore into a major pharmaceutical manufacturing hub. As can be seen from Annex Table 1A, pharmaceutical manufacturing output in Singapore grew rapidly between 1990 and 2004, with average growth per annum exceeding $20 \%$, reaching $\$ \$ 415.2$ billion in 2004 . In terms of value add contribution, the pharmaceutical sector in 2004 contributed $19 \%$ of total manufacturing output, up from less than 5\% in 1990 (see Annex Table 1B). Reflecting the high capital intensity and scale of operations of such manufacturing activities, the average capital per worker for the industry amounted to $\$ \$ 0.9$ million per worker in 2003 , while the average output per firm was $\$ \$ 255$ million, both significantly above the average of all manufacturing. Virtually all of the 40 pharmaceutical manufacturing firms in operation in Singapore in 2004 are foreign majority owned. Annex Table 2 provides summary profile of some of the leading global pharmaceutical companies with significant manufacturing operations in Singapore.

Table 2a R\&D expenditure \& manpower in the biomedical sector ${ }^{1}$ (S\$ million), 1993-2004

\begin{tabular}{|c|c|c|c|c|c|c|}
\hline Year & $\begin{array}{l}\text { Private } \\
\text { sector }\end{array}$ & $\begin{array}{l}\text { Higher education } \\
\text { sector }\end{array}$ & $\begin{array}{l}\text { Government } \\
\text { sector }\end{array}$ & $\begin{array}{l}\text { PRIC } \\
\text { sector }\end{array}$ & Total & $\begin{array}{l}\text { Total } \\
\text { RSEs }^{2}\end{array}$ \\
\hline 1993 & 3.6 & 32.1 & 7.4 & 0.0 & 43.1 & 447 \\
\hline 1994 & 5.0 & 39.5 & 14.8 & 0.0 & 59.4 & 386 \\
\hline 1995 & 29.1 & 37.0 & 15.3 & 0.0 & 81.8 & 570 \\
\hline 1996 & 7.8 & 42.4 & 18.2 & 0.1 & 68.5 & 507 \\
\hline 1997 & 15.0 & 47.5 & 25.2 & 3.5 & 91.2 & 556 \\
\hline 1998 & 24.8 & 52.1 & 35.6 & 5.9 & 118.3 & 625 \\
\hline 1999 & 37.1 & 53.1 & 29.1 & 3.6 & 122.9 & 654 \\
\hline 2000 & 47.0 & 62.5 & 32.5 & 15.6 & 157.6 & 1333 \\
\hline 2001 & 88.4 & 87.3 & 57.9 & 77.1 & 310.7 & 2055 \\
\hline 2002 & 147.4 & 106.8 & 87.5 & 121.5 & 463.1 & 2150 \\
\hline 2003 & 149.3 & 87.6 & 91.8 & 46.7 & 375.4 & 2504 \\
\hline 2004 & 238.1 & 124.9 & 116.7 & 280.7 & 760.4 & 2238 \\
\hline
\end{tabular}

1 Includes biomedical sciences and biomedical engineering. From 2002 biomedical \& related sciences and biomedical engineering

2 RSE: No. of full-time equivalent Research Scientists and Engineers

Source: National Survey of $R \& D$ in Singapore (various years), Agency for Science, Technology and Research (previously National Science \& Technology Board) 
Table 2b Biomedical share of total Singapore R\&D expenditure \& manpower by sector (\%), 1993-2004

\begin{tabular}{lllllll}
\hline Year & $\begin{array}{l}\text { Private } \\
\text { sector }\end{array}$ & $\begin{array}{l}\text { Higher education } \\
\text { sector }\end{array}$ & $\begin{array}{l}\text { Government } \\
\text { sector }\end{array}$ & $\begin{array}{l}\text { PRIC } \\
\text { sector }\end{array}$ & Total & Total RSE \\
\cline { 1 - 3 } & \multicolumn{2}{c}{ \% of total Singapore R\&D expenditure } & & \% of Singapore RSEs \\
\hline 1993 & 0.6 & 20.4 & 6.9 & 0.0 & 4.3 & 6.7 \\
1994 & 0.7 & 22.0 & 10.4 & 0.0 & 5.1 & 5.4 \\
1995 & 3.3 & 19.2 & 13.9 & 0.0 & 6.0 & 6.8 \\
1996 & 0.7 & 17.8 & 10.9 & 0.0 & 3.8 & 5.0 \\
1997 & 1.1 & 17.1 & 11.6 & 1.2 & 4.3 & 4.9 \\
1998 & 1.6 & 17.0 & 11.9 & 1.7 & 4.7 & 4.9 \\
1999 & 2.2 & 17.1 & 9.5 & 1.0 & 4.6 & 4.7 \\
2000 & 2.5 & 18.5 & 13.7 & 4.1 & 5.2 & 7.3 \\
2001 & 4.3 & 23.8 & 20.3 & 19.5 & 9.6 & 11.1 \\
2002 & 7.0 & 23.8 & 21.1 & 28.0 & 13.6 & 11.1 \\
2003 & 7.2 & 19.1 & 26.4 & 46.4 & 11.0 & 11.8 \\
2004 & 9.2 & 29.4 & & & 18.7 & 14.6 \\
\hline
\end{tabular}

Source: Same as Table 2a

As part of her strategic shift towards a knowledge-based, innovation-driven economy, the government of Singapore began fine-tuning the global MNC leveraging strategies since the mid-1990s by putting increasing emphasis on attracting global MNCs to conduct R\&D activities in Singapore, either as an extension of existing manufacturing operations, or as de novo standalone R\&D operations. The expansion of R\&D activities by foreign firms in Singapore contributed significantly to the rapid growth in recent years of the aggregate R\&D/GDP ratio in Singapore, which increased steadily from only $0.3 \%$ in 1981 to $0.9 \%$ in 1990 and $1.9 \%$ in 2000 , reaching $2.3 \%$ by 2004 , a level that exceeds those of many OECD countries (Wong, 2005). Foreign firms accounted for more than one-third of total national R\&D expenditure and $60 \%$ of total private sector $\mathrm{R} \& \mathrm{D}$ in the more recent years.

\subsection{Life science strategies}

As part of the overall intensification of investment in $R \& D$ and innovation, the Singapore government announced in 2000 a strategic shift towards the promotion of biomedical science and technology as a leading sector in the economy for the 21st century, and as a means to diversify from its previous high dependence on IT/ electronics manufacturing. The vision is to turn Singapore into Asia's premier hub for biomedical sciences, with world-class capabilities across the entire value chain, from basic research to clinical trials, product/process development, full-scale manufacturing and healthcare delivery (Biomed-Singapore, 2003). To achieve this vision, a US\$1 billion fund was initially allocated to boost public investment in several new life science research institutes, to co-fund new R\&D projects by global pharmaceutical firms, as well as to initiate the building of a new life science complex called Biopolis. Additional public funding was further announced to sustain the growth of the life science cluster beyond 2006.

Since the announcement of the new initiative, the government has moved decisively in terms of implementation (see Finegold et al., 2004 and Tsui-Auch, 2004 for more details). A new Biomedical Research Council (BMRC) was established in the 
Table 3 Share of life science patents in Singapore, 19772004

Note: Singapore assigned patents and patents with at least one Singapore inventor Source: Calculated from USPTO database

\begin{tabular}{llcl}
\hline Year & $\begin{array}{l}\text { Life science } \\
\text { patents }\end{array}$ & Total patents & $\begin{array}{l}\text { Life science } \\
\text { patents/total } \\
\text { patents (\%) }\end{array}$ \\
\hline $1977-1991$ & 5 & 187 & 2.7 \\
$1992-1999$ & 26 & 969 & 2.7 \\
$2000-2004$ & 55 & 2486 & 2.2 \\
Total & 86 & 3642 & 2.4 \\
\hline
\end{tabular}

revamped public agency responsible for public R\&D funding (A*STAR, formerly known as NSTB) to allocate R\&D funding to strategic biomedical research areas. Four new public research institutes (PRIs) in bioinformatics, genomics, bioprocessing and nanobiotechnology were established over the period 2000-2002, while the existing Institute of Molecular \& Cell Biology (IMCB) was expanded (see Annex Table 3). Public fund amounting to $\$ 200$ million has been committed to three bioscience venture capital funds to fund start-up of DBFs in Singapore as well as to attract DFI by overseas DBFs in Singapore. A further $\$ 100$ million has also been earmarked for attracting up to five globally leading corporate research centres.

The four new life science-related public research institutions have all been located in Biopolis, a new physical hub for life sciences costing $\mathrm{S} \$ 500$ million when completed that is intended to make Singapore a world-class life science R\&D hub for the Asian region. Dedicated to biomedical R\&D activities and designed to foster a collaborative culture among the institutions present and with the nearby National University of Singapore, the National University Hospital and Singapore's Science Parks, the Biopolis also provides integrated housing and recreation facilities for the many foreign scientists to be attracted to work in the research facilities.

Because of the ambitious scale and speed of development, the attraction of foreign talents has become an integral part of the government's life science strategy. Not only would it have taken much too long for the local university to train and develop the large number of scientists needed to staff these major new research institutes, there was also a dearth of local star researchers with sufficient international reputation and stature who can serve as the initial magnet to attract other younger researchers (Zucker \& Darby, 1996). Consequently, the government focused much attention initially on attracting several internationally renown scientists, including Sidney Brenner, a Nobel laureate; Alan Colman, the leading transgenic animal cloning scientist from Scotland's Roslin Institute; Edison Liu, the former head of the US National Cancer Institute; Sir David Lane, the former director of Cancer Research UK's Cell Transformation Research Group; and Yoshaki Ito, a leading Japanese cancer researcher who recently retired from a leading Japanese university. The directorship of the new Nano-Biotechnology Institute also went to a young rising star researcher from MIT, Jackie Ying. Other star researchers talent-spotted include Axel Ullrich, a well-known molecular biologist from Max Planck Institute for Biochemistry, and Markus Wenk, a noted biophysicist and lipid researcher from Yale (Traufetter, 2005).

Although most of these new PRIs maintain some affiliation with the National University of Singapore, they have been funded separately by the BMRC and are 
largely autonomously operated with their own management and advisory board that report directly to the BMRC.

The government has also intervened significantly in the development of a specialized life-science venture capital industry. Although a relatively sizable venture capital industry had emerged in Singapore (driven partly by initial government's injection of funds as LPs) by the end of 2000, there was hardly any local expertise on life science related VC investing, due to the lack of a critical mass of life science DBFs in Singapore. Consequently, the government took a lead role in directly running a number of life-science related funds, which were subsequently centralized under one fund management umbrella called Bio*One Capital. To-date, Bio*One Capital reported investment in 36 portfolio companies in the area of drug discovery/ development, cellular therapy, medical technology, and protein therapeutics/ monoclonal antibody. Bio*One also invested funds in five other life-science VC funds, perhaps as an inducement for these fund to operate in Singapore. Although many of the portfolio companies of $\mathrm{Bio}^{*}$ One were originally founded outside Singapore, the fund had been instrumental in getting some of them to move some operations into Singapore. For example, Bay Area-headquartered Fluidigm had chosen Singapore to locate her first Asian manufacturing operation.

Through support activities such as Bio*One, a fledgling DBF sector comprising over twenty firms has emerged in Singapore (see Annex Table 4). Although still relatively small when compared to the leading biotech clusters in the world, the record is actually creditable, given that there were virtually no such DBFs 7-8 years ago. Complementing these DBFs, about a dozen global pharmaceutical companies as well as a number of independent contract research organizations (CROs) have also been attracted to establish some R\&D operations in Singapore (see Annex Table 2).

Reflecting the growing emphasis on life science research, the share of total R\&D expenditure in biomedical fields rose sharply from less than 5\% in the 1990 s to over $18 \%$ by 2004 (see Table 2). However, symptomatic of the long gestation nature of much of biomedical research, the share of biomedical-related patenting in total output of patenting by Singapore-based inventors continued to lag behind its share of R\&D spending. As can be seen from Table 3, while the cumulative number of biomedical patents granted by USPTO to Singapore-based inventors and Singaporebased organizations more than doubled in the five years 2000-2004 compared to

Table 4 Profile of National University of Singapore (NUS) (FY 2004/5)

\section{Thomson ISI-indexed journal articles only}

Source: NUS Annual Research Report 2003-2004, National University of Singapore; NUS Annual Report 2005, National University of Singapore; Database of the USPTO

\begin{tabular}{ll}
\hline Indicator & FY 2004/5 \\
\hline Faculty members (end June 2005) & 1,765 \\
Research staff (end June 2005) & 1,087 \\
Undergraduate students enrolled & 21,761 \\
Graduate students enrolled & 6,461 \\
Total research funding & $\mathrm{S} \$ 157.6 \mathrm{mil}$ \\
Journal publications in SCI/SSCI (CY 2004) & 2,930 \\
Patents filed & 124 \\
Patents granted & 51 \\
Cumulative US patents granted (CY1990-2004) & 162 \\
Cumulative journal publications & 21,760 \\
$\quad$ (Jan 1995-June 2005) & \\
\hline
\end{tabular}


before 2000, the share of biomedical patents in total patents granted actually declined slightly (from $2.7 \%$ before 2000 to $2.2 \%$ for the five years 2000-2004).

Consistent with the larger role of public sector (including universities) in life science research, two-thirds of biomedical R\&D expenditure in Singapore in the 2000-2004 period were conducted by public organizations, versus about one third for non-biomedical R\&D. Taking into account the financial incentives given to some private sector pharmaceutical firms to conduct R\&D in Singapore, the share of public funding in R\&D spending in Singapore is likely to be larger than two-thirds. It is also interesting to note that, while biomedical R\&D accounted for only $15 \%$ of total research scientists and engineers (RSEs), it accounted for close to one-quarter of all $\mathrm{PhD}$ holders in $\mathrm{R} \& \mathrm{D}$.

Notwithstanding this recent rapid growth in importance of life science R\&D in Singapore, it is important to recognize that, compared with the advanced countries that are the world leaders in biomedical science and technology, the scale and intensity of Singapore's biomedical R\&D remains modest. For example, Singapore's total annual biomedical R\&D spending of about US $\$ 450$ mil. is about $1 \%$ of US federal annual funding for biomedical R\&D (estimated at US\$38 billion in 2002). Even in terms of intensity, Singapore's biomedical share of around $12 \%$ of total national R\&D is still substantially lower than that of UK and US (over $25 \%$ ). Finally, biomedical technology output from Singapore in 2004 amounted to about S $\$ 2$ billion, only $13 \%$ of the total pharmaceutical manufacturing output in Singapore in the same year (BMS, 2006).

In addition to direct commitment of public funding, the government also significantly changed the regulatory and promotional landscape for life science industry development in Singapore. Exploiting the ban on new stem cell lines in the US, the Singapore government allowed, and indeed strongly promoted, the establishment of stem-cell research in Singapore, enabling the island state to gain a beachhead for stem-cell based work (Chang, 2001). The government also established various promotional initiatives designed to make Singapore a regional hub for life sciencerelated conferences, publishing and networking, as well as putting in place a tighter bioethics policy framework governing life science research, after a controversial case involving alleged breach by a noted researcher recruited from Cambridge University (see Annex Table 5 for a summary of major milestones of life science industry development in Singapore). Last, but not least, the government also hastened the move towards increasing competition in the national healthcare system, including greater liberalization and transparency of pricing of healthcare services, and greater

Table 5 Ranking of NUS in the World University rankings by the Times Higher Education Supplement, 2004-2005

\begin{tabular}{lcc}
\hline & 2004 ranking & 2005 ranking \\
\hline Overall & 18 & 22 \\
Biomedicine & 25 & 15 \\
Science & 35 & 34 \\
Technology & 9 & 9 \\
Social Sciences & 10 & 13 \\
Arts and Humanities & 17 & 56
\end{tabular}

Source: Knowledge Enterprise Online, various issues, downloaded from http://www.newshub.nus.edu.sg/; The Times Higher Education Supplement (various years)

Springer 
autonomy among the public hospitals in introducing innovations to gain competitive advantage. In addition, the government is promoting Singapore as a regional healthcare hub by inviting foreign healthcare players to invest in Singapore, further exerting competitive pressure on the public hospitals to improve their operational efficiencies.

\section{Changes to internal university policy contexts for life science commercialization}

\subsection{Overview of National University of Singapore (NUS)}

Established in 1905, National University of Singapore (NUS) has been the oldest and largest public university in Singapore, with a total student enrolment of over 34,000 (two-third of which are undergrads). Although there are two other public universities in Singapore, both were newer and not as comprehensive in scope (NTU was established in 1965 and until recently primarily focused on engineering, applied science, accounting and business, while SMU was only established in 2000 and focuses on management and economics education). Besides enjoying higher reputation and a much stronger overall track record in terms of internationally refereed research publications, NUS has also established a strong lead in terms of patenting records than NTU. In addition, with the only medical school and faculty of science, NUS had a practical monopoly on biomedical research and education. Although this is likely to change in the future with the establishment of a new medical school and a new school of life sciences in NTU in 2004, for the purpose of this study, I confine my analysis on NUS.

Table 4 provides a summary profile of NUS. With an annual R\&D budget of about S\$158 million in 2004, NUS alone constitutes almost 5\% of total R\&D spending in Singapore. With 162 US patents, NUS is also the third largest patent holder in Singapore, after Chartered Semiconductor (a local firm) and HP (a foreign MNC subsidiary). Despite being a relatively late comer, NUS has begun to attract international recognition of her research capabilities and educational standards, as reflected by her surprisingly high ranking in the recent Times Higher Education Supplement's annual rankings of top 200 universities in the world (see Table 5), both overall as well as for individual faculties. In particular, NUS was ranked 15 th in the field of Biomedicine in 2005, up from 25 in 2004.

\subsection{Recent shift towards entrepreneurial university model}

Like most other public universities developed under the British Commonwealth tradition, NUS has in the past been following the traditional model of having teaching as her primary mission, with research as a secondary function. While the 1980s and 1990s saw increasing emphasis on research, it was only in the mid-1990s that NUS established a technology licensing office.

The major impetus for change came only at the end of the 1990s, when a new vice-chancellor was appointed who enjoyed the strong support of the deputy prime minister who oversaw tertiary education. Harvard-trained and having prior background in US industry (General Electric) and research administration experience at an Ivy-League university in the US, the new vice chancellor not only 
significantly accelerated the pace of change of several initiatives that were already in motion earlier, but more importantly, he initiated a shift towards what Etzkowitz et al. (2000) has described as the "entrepreneurial university" model. Emphasizing the need to make the university more entrepreneurial, he created a new division in the university that has come to be known as NUS Enterprise, and hand-picked as the CEO of the new organization a professor from the engineering school who had been among the earliest to spin-off a company to commercialize his invention. Under the broad mission to inject a more entrepreneurial dimension to NUS education and research, the $\mathrm{CEO}$ was given great latitude to define and implement new initiatives to make the university "more enterprising". After some early experimentation, NUS Enterprise began to re-shape a number of key university policies with respect to governance of technology commercialization. Among the key changes introduced, the technology licensing office was re-organized to become more "inventor friendly", with less emphasis on maximizing licensing revenue, and greater focus on getting greater deployment of NUS technology to the marketplace, whether through licensing to existing firms or spinning off new firms. A new Venture Support (NVS) unit was also created with the explicit aim of providing assistance to NUS professors to commercialize their inventions and knowledge. Besides the provision of Incubator facilities, NVS also launched a seed fund that providing seed funding to NUS spinoff companies. A student start-up fund was also established to provide seed funding to new ventures started by students.

In terms of education program, a university level Entrepreneurship Centre was also established within NUS Enterprise with the mission to teach entrepreneurship to all students on campus, particularly students in engineering, computing and science, including life science and medical students. The centre was also given the task of building a network of entrepreneurs, venture capitalists and angel investors to provide NUS spin-offs with mentoring by practitioners and access to external venture funding.

Besides pushing for greater enterprise, the new university vice-chancellor also seeks to "globalize" the university, arguing that, with growing global competition for faculty, students and resources, NUS needs to adopt globally competitive governance and practices to stay competitive. Indeed, he adopted "Towards a Global Knowledge Enterprise" as the vision statement for NUS. Under this globalization drive, he began to shift the emphasis away from local manpower development to incorporate a twin objective of making the university a global educational hub, attracting top foreign students and faculty in increasing competition with other leading universities in the world. In line with this globalization drive, NUS began revising her faculty compensation and policy, making it more flexible to allow the university to pay more to attract top talents. Tenure and promotion policy was made much more stringent and performance-based in line with the benchmarks of leading universities in the US. Intake of foreign students also increased, while a larger share of local students are encouraged to go on exchange program abroad for at least a semester.

A new initiative that integrated both dimensions of globalism and entrepreneurship was introduced via NUS Enterprise-the so-called NUS Overseas College Program (NOC), under which the university would send her brightest undergraduate students to five entrepreneurial hubs in the world to work as interns in high-tech start-up companies for one year, during which they would also take courses related to entrepreneurship at partner universities in each of the regions. The first NOC

望 Springer 
program was launched in Silicon Valley in 2002, followed by Philadelphia in 2003, Shanghai in 2004, Stockholm in 2005, and Bangalore in India in 2006. The choice of Philadelphia is noteworthy, as it was deemed a major hub for pharmaceutical companies and hence serves to nurture entrepreneurial interest in life sciences in particular.

\subsection{NUS' life science strategies}

Besides the broad shift towards a US-model of university governance for attracting and keeping talent, international benchmarking for promotion \& tenure, and "inventor-friendly" technology commercialization policy, the university also made specific policy and organizational changes in life science education and research. An Office of Life Sciences (OLS) was set up formally in 2001 with the mission to make NUS into a world-class hub for life sciences. It aims to accomplish its mission by coordinating, integrating and facilitating Life Science throughout the University and affiliated institutions. In line with the Government's emphasis on Life Sciences as the next pillar of Singapore's economy, the OLS is also charged with launching new research initiatives and teaching programs.

Among the new educational initiatives that OLS has introduced include a new integrated Life Science Undergraduate Major Program that involves the participation of five core faculties (Computing, Dentistry, Engineering, Medicine and Science). A new bio-engineering division was also set up in the Engineering School that crosses traditional departmental boundaries within the school.

In terms of research, OLS also brought together researchers from the five core faculties to collectively identify and agree to 10 strategic areas of research, grouped under two broad headings of Diseases and Platform Technologies. Under Diseases, the priority areas identified comprise Cancer, Neurobiology/Ageing, Vascular Biology/angiogenesis, Hepatology and Infectious Diseases. Under Platform Technologies, the five priority areas identified consist of Bioinformatics /Registries/ Molecular Epidemiology, Structural Biology/Proteomics/Genomics, Immunology, Bioengineering and Experimental Therapeutics /Medicinal Chemistry/Toxicology/ Clinical Trials. In forging consensus on these 10 core areas, OLS hoped to ensure greater strategic focus of research within NUS as well as to provide strategic directions for developing new collaboration with other research institutes within and outside NUS, as well as with renowned international institutes.

As a further indicator of the strong commitment of NUS to strengthen her life science expertise, the university recently obtained approval by the government to establish a second medical school. Unlike the existing medical school, which is in the British tradition of taking students directly from high schools, the new school was modeled after the US post-graduate, professional medical school, with students drawn from graduates from various disciplines and faculty recruited to emphasize research excellence. The school was established in collaboration with a leading US medical school (Duke University), and was located next to the largest public hospital (Singapore General Hospital) to facilitate close interactions, particularly in research and clinical trials. Through this new initiative, NUS as a university is now closely linked to the two largest public hospitals in the country through two different medical school models, thereby encouraging competition and exploration of different innovative models in university-industry collaborations. 


\subsection{Summary of changes to the Triple-Helix nexus for life science commercialization}

Table 6 summarizes the key changes among the actors in the Triple-Helix nexus for life science in Singapore. In essence, at the risk of over-simplification, the period of

Table 6 Summary of changes in the Triple-Helix Nexus for life science in Singapore

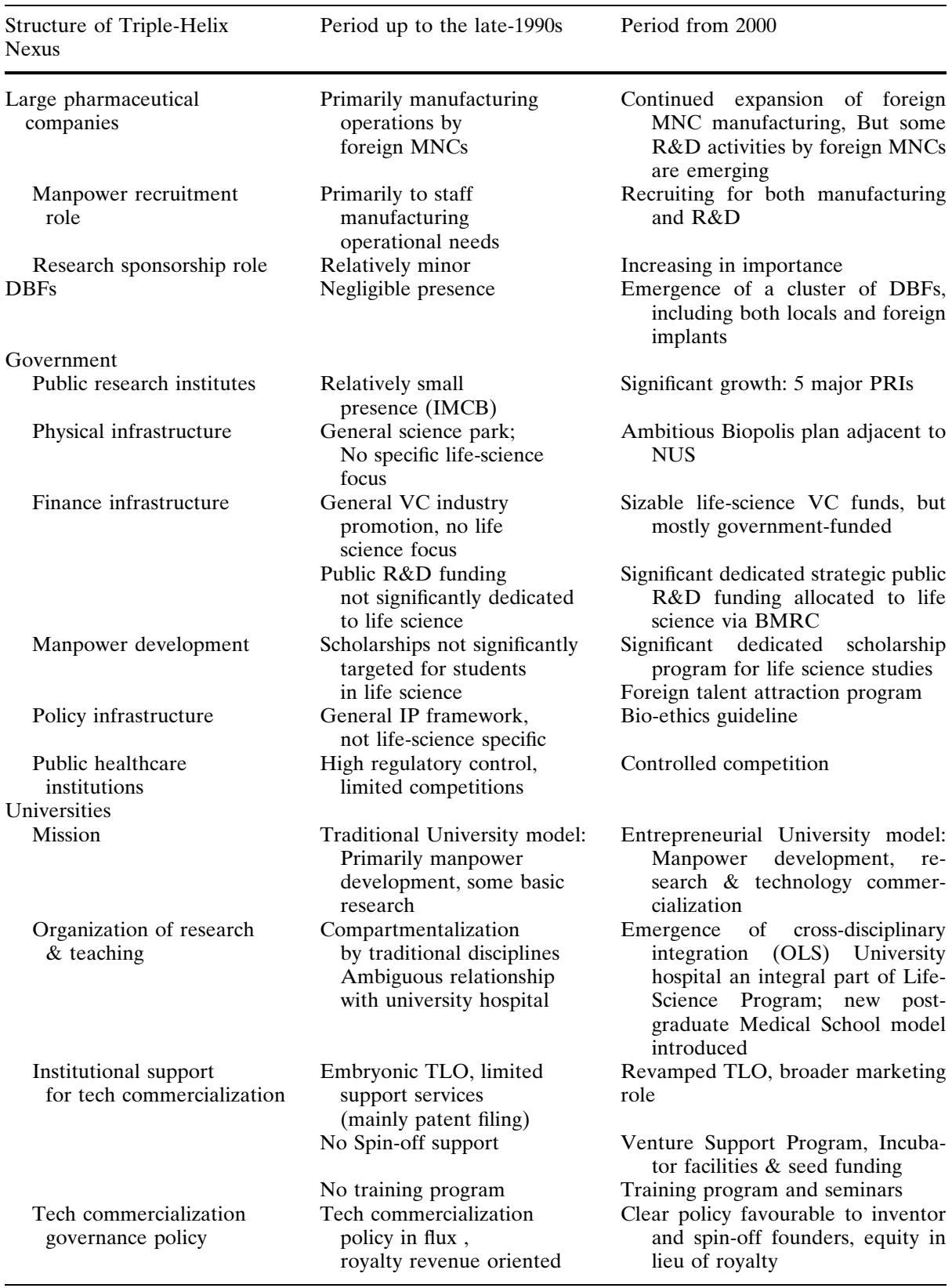


the early 2000s can be characterized as a period of great flux, with the role of government dramatically increased, an embryonic DBF sector starting to emerge alongside increased R\&D presence by subsidiaries of global pharmaceutical firms. At the same time, the university sector itself, both responding to the new government and industry agenda on life science as well as the university's own effort to reform itself, began transition from a traditional teaching school model to the "entrepreneurial university" model.

As can be seen from Table 6, the impacts of the changing government and industry contexts on NUS are multi-faceted, having both competitive as well as synergistic elements. For example, the PRIs were generally able to offer more flexible and generous employment packages, not to mention the prestige of having anchor star researchers and newer facilities and equipment, and thus created competitive pressures on NUS in terms of scientific manpower recruitment. Their strong research focus on key strategic areas also made them more attractive partners than NUS for collaboration with global MNCs in some cases. On the other hand, with the close proximity of Biopolis to NUS, potential synergies are being created where NUS research competence may be complementary to the PRIs. The growth of the embryonic DBF sector has so far not been sufficiently large to draw talents away from NUS, although the potential for conflict may exist in the future, as occurred in other leading biotech hubs in the world.

\section{Impacts on university life science commercialization}

\subsection{Overview of NUS life science commercialization performance}

Consistent with her significant role in biomedical research in Singapore, NUS represents the single largest biomedical patent holder in Singapore, accounting for 25 out of 86 US patents granted in the field of biomedical technology over the period 1996-2004, or nearly one-third (see Table 7). However, these 25 biomedical patents represent only $16.0 \%$ of all patents granted to NUS, a share that is lower than electrical and electronics (32\%) and computer technology (25\%) (Table 8). Compared to the estimated $25 \%$ biomedical share of total R\&D expenditure in NUS

Table 7 Breakdown of Singapore life science patents by assignee, 1977-2004

\begin{tabular}{llr}
\hline & No. of patents & $\%$ \\
\hline Private & 32 & 37.2 \\
NUS & 25 & 29.1 \\
Government and PRIC & 16.5 & 19.2 \\
Individual/unassigned & 11 & 12.8 \\
Other IHL (foreign) & 1.5 & 1.7 \\
Total & 86 & 100.0
\end{tabular}

Note: Singapore assigned patents and patents with at least one Singapore inventor. Two patents had two assignees; half a count was given to each assignee

Source: Calculated from USPTO database. Following the NBER technological categories, life science patents are taken to be those in drugs, surgery and medical instruments, biotechnology and miscellaneous-drugs and medical 
Table 8 Breakdown of NUS patents by technology category, 1990-2004

\begin{tabular}{lcc}
\hline Technology category & No. of patents & $\%$ \\
\hline Electrical \& Electronic & 52 & 32.1 \\
Computers \& Communications & 40 & 24.7 \\
Chemical & 24 & 14.8 \\
Life sciences & 26 & 16.0 \\
Mechanical & 13 & 8.0 \\
Others & 7 & 4.3 \\
Total & 162 & 100 \\
\hline
\end{tabular}

Note: The NUS figure for life sciences does not correspond to that given in Table 7 because a full patent was counted to NUS even when it was jointly assigned

Source: Calculated from USPTO database

in recent years, the above suggests that the $\mathrm{R} \& \mathrm{D}$ cost to generate commercializable IP in the biomedical field is higher than in other disciplines.

In terms of spin-off companies, 11 out of over 40 companies $(25 \%)$ that were spun-off by NUS up to 2004 were in biomedical related fields. As can be seen from Annex Table 6, virtually all the companies were in biomedical technology rather than in therapeutic drug discovery. Moreover, the amount of external venture funding attracted by these spin-offs remained modest, with the majority being funded by the founders themselves and business angel investors, rather than by formal VC firms.

In terms of technology licensing, NUS' market reach has been somewhat more extensive. Not counting a number of prior biomedical licenses that had expired, there were 31 active licensees of biomedical related patents, ranging from NUS spinoffs to local DBFs and global pharmaceutical companies at the end of 2004. Although the cumulative amount of royalties generated to-date was not published, it was likely to remain modest, since the majority of the licensing deals were concluded only over the last 2-3 years.

Overall, the aggregate statistics shows that the extent of biomedical technology commercialization from NUS, while still relatively modest, has visibly increased in recent years, both in terms of licensing deals as well as formation of spin-off companies. Seven of the eleven biomedical spin-offs were from 2000 onwards, as were the majority of the licensing deals.

The above aggregate picture is further reinforced by my findings from several indepth case studies conducted with founders and inventors from NUS. In particular, it is instructive to compare and contrast the experience of two faculty members who sought to start their own biomedical ventures, one before the recent policy shift towards technology commercialization, and one after.

Lynk Biotechnology was founded by Assoc. Prof. Lee Chee Wee at the beginning of 2000, after he received US $\$ 1$ million angel investor seed funding. Although the initial plan for the company was to focus on drug discovery work, this was abandoned when the company ran out of money and could not secure any follow-on VC investment. It also did not help that the technology licensing office at NUS at that time drove a hard bargain in terms of licensing negotiation, resulting in the company having to pay a hefty upfront royalty fee to the university. The founder was also not 
able to rent any part of his university lab facility to conduct research for his company, and had to move out to commercially rented facility outside the university.

Concluding from his experience that the classic US model of drug development would not work in Singapore, he subsequently changed his business model to developing health supplements that do not require FDA approval, as well as new trans-dermal techniques for delivery of approved FDA compounds. Pouring in his own money to fund his new business model, and without any help from NUS, he was able to develop a number of products (including a cream for relieving arthritis pain) that started to generate good revenue. With annual revenue reaching $\$ \$ 5$ million, the company managed to attract in late 2004 a $\$ \$ 2.5$ million investment by a local private equity firm Whiterock Investments that specializes in medical technology. With the new investment, the company was able to embark on a new research and production facility not only to expand his current production, but also to support his earlier proteomics research work. The company also started development work to make biodegradable soaps for industry.

In contrast to the earlier experience of Lynk Biotechnology, a more recent biomedical-related venture, Chiral Sciences, has a much smoother start-up experience. Co-funded by two professors from the chemistry department in 2002 to commercialize their technique for separating left-handed molecules from right-handed ones, the company was able to quickly obtain an exclusive technology licensing agreement with NUS that involved equity in exchange of royalty payment. The company also received seed funding from NVS Seed Fund in 2004 on fairly generous terms, and was given space in the NVS Business Incubator to operate. Financial assistance was also given to the company to co-finance a trip to the US to pitch to potential venture capitalists and to seek prospective business partners.

The experience of two other life science inventors in licensing their technologies to large pharmaceutical companies over the two different periods also prove instructive. A husband and wife team of microbiologists, the two professors were among the first NUS faculty members in the life science field who became interested in commercializing their inventions in the early-1990s. Their interests initially grew not out of encouragement by NUS, but from a visiting professor from the US who pointed out to them the commercial potential of their discoveries. Lacking prior experience-they did not even know what a patent was at that time-they went to the then relatively newly established NUS technology licensing office to help them prepare and file several patents. Although the patents were eventually filed and granted, they found that the process was more costly and incurred longer delay than should have been the case, due to lack of experience on the part of the technology licensing office at NUS at the time. Moreover, they found that the office was of no help in the subsequent marketing of their patented technology; not only did they have to spend their own money to go on road-shows in the US and UK to pitch to potential licensee companies, they also found that there was little follow-up by the NUS technology licensing office on the leads they provided. In the end, their invention was serendipitously discovered by an American company, after the company CEO saw a BBC TV program where the two researchers were interviewed on their discovery. This led to the eventual licensing of their technology to the US company, but on terms that in hindsight may have been less favourable than it could have been, had the NUS licensing office conducted a more thorough due diligence on the potential value of the invention to industry. The two professors also had a second invention 
in the late 1990s that they tried to license to local industries without any success, as none of them was interested in investing in the further work needed to develop their invention into end products. In the end, the technology was licensed to another foreign company (in UK), which provided the specialized legal expertise to draft the patent. By the time the pair came out with yet another discovery in 2003, however, they were able to find much more assistance from the NUS technology licensing office, which by then had divisionized its operation into separate technology areas staffed by better qualified specialists, including one on life science. Assistance in marketing and publicity was also provided. Suitably encouraged, the two professors are now seriously considering commercializing their latest invention through their own spin-off company instead of licensing to external parties.

As these three cases illustrate, there had been tangible improvements in the NUS technology commercialization policy and infrastructure support in recent years. Nonetheless, this had not led to any drug discovery-type of spin-off from NUS yet. Interestingly, a number of applications proposing drug development could not be considered for funding by the NVS seed fund, because its charter was limited to seed funding ventures that have a good prospect of receiving a sizable follow-on external funding by VCs or business angels, and none of the life science VCs operating in Singapore expressed any interest. Thus, there appears to be a limit to what the university on its own can do to encourage drug-discovery type of commercialization; the external venture support ecosystem also needs to further improve. In contrast, NUS was better able to facilitate the commercialization of biomedical technologies that have lower investment requirements or shorter gestation period to bring products to market: All eight NUS spin-offs in the biomedical field so far are in biomedical equipment, bioinformatics and non-drug products.

\section{Conclusion}

Singapore's strategy to develop the island state into a leading biomedical hub in the world has emphasized leveraging foreign firms and talents. This has been manifested in a much stronger emphasis on creating new de novo public research institutions to host largely imported foreign scientific talents, as well as attracting foreign MNCs to extend R\&D operations in Singapore in addition to manufacturing operations. The development of indigenous capabilities of the local universities is emphasized, but perhaps at a lower level of priority, partly because of limitations on how fast and how much the local universities can be adapted to meet the national agenda.

Notwithstanding this, my analysis of the changes in policies and organizations of NUS, the largest and leading research-based university in Singapore, shows that the university has responded relatively quickly to the changing national agenda. Although these changes have not yet led to significant commercialization leading to major new drug-discovery, there has been a tangible increase in the pace of spin-offs and technology licensing in areas such as bioinformatics, biomedical equipment and non-therapeutic products, where the venture financing requirements are less daunting. 
While the focus on fast execution by the Singapore government, no doubt motivated by a concern for seizing advantages in a global competitive race, necessitated the strategy of high reliance on foreign talents and firms, this strategy carries a longer term risk of indigenization failure (Tsui-Auch, 2004). A key challenge is therefore how to ensure a sufficient number of foreign talents would eventually decide to settle down in Singapore. While a variety of incentives have been offered by the Singapore Government to retain foreign talents, including investment in cutting edge R\&D facilities, ready availability of research grants, practice of meritocracy and offer of citizenship, coupled with conducive factors such as cosmopolitan culture, excellent international schools and a clean and green living environment, how successful Singapore is in retaining the various top foreign scientists remains to be seen, given that the government of the home countries of these scientists are likely to want to attract them back in the future.

The experience of NUS suggests that universities in developing economies need to make a transition from the traditional university model to the "entrepreneurial" university model before they can play an effective role in the Triple-Helix nexus for commercialization of life science. Otherwise, the local universities risk being marginalized, as government development agencies, in their haste to catch up in the global biotech race, put priority on autonomous public research institutes. However, while the shift towards the entrepreneurial university model can arguably speed commercialization of university biomedical technologies that have shorter gestation and lower financing requirements, major drug discovery efforts are unlikely to result from policy changes at the university level alone; more fundamental changes in the overall life science eco-system, including the presence of sophisticated life science venture capital, access to big pharmaceutical companies, and collaborative links with local hospitals, are necessary.

Last but not least, the experience of Singapore also suggests the need for policy makers to pay greater attention to ensuring a more balanced Triple-Helix structure of university-government-industry linkage in life science cluster development. In particular, while there is a temptation by government developmental agencies to favor autonomous public research institutes to spearhead life science $\mathrm{R} \& \mathrm{D}$ in the short-run, this may be counter-productive in the long-run without a synergistic integration between the public research institutes and the local universities (Lehrer \& Asakawa, 2004). While emphasizing the development of PRIs, the Singapore experience suggests that the role of local universities has not been neglected. In the global race among nations to develop biotech industrial capabilities, Singapore's competitive edge may well be her adaptive ability to evolve quickly and flexibly a balanced Triple-Helix nexus of players from the private, government and university sector. Despite starting relatively late, Singapore's track record in rapidly putting in place the key Triple-Helix elements through an aggressive and targeted policy of attractive foreign companies and talents, a strong public sector commitment in investing in PRIs and supporting infrastructure, and a responsive university with an entrepreneurial orientation, provides ground for optimism that Singapore will indeed emerge as a major biotech industrial hub in the world in the longer run. 


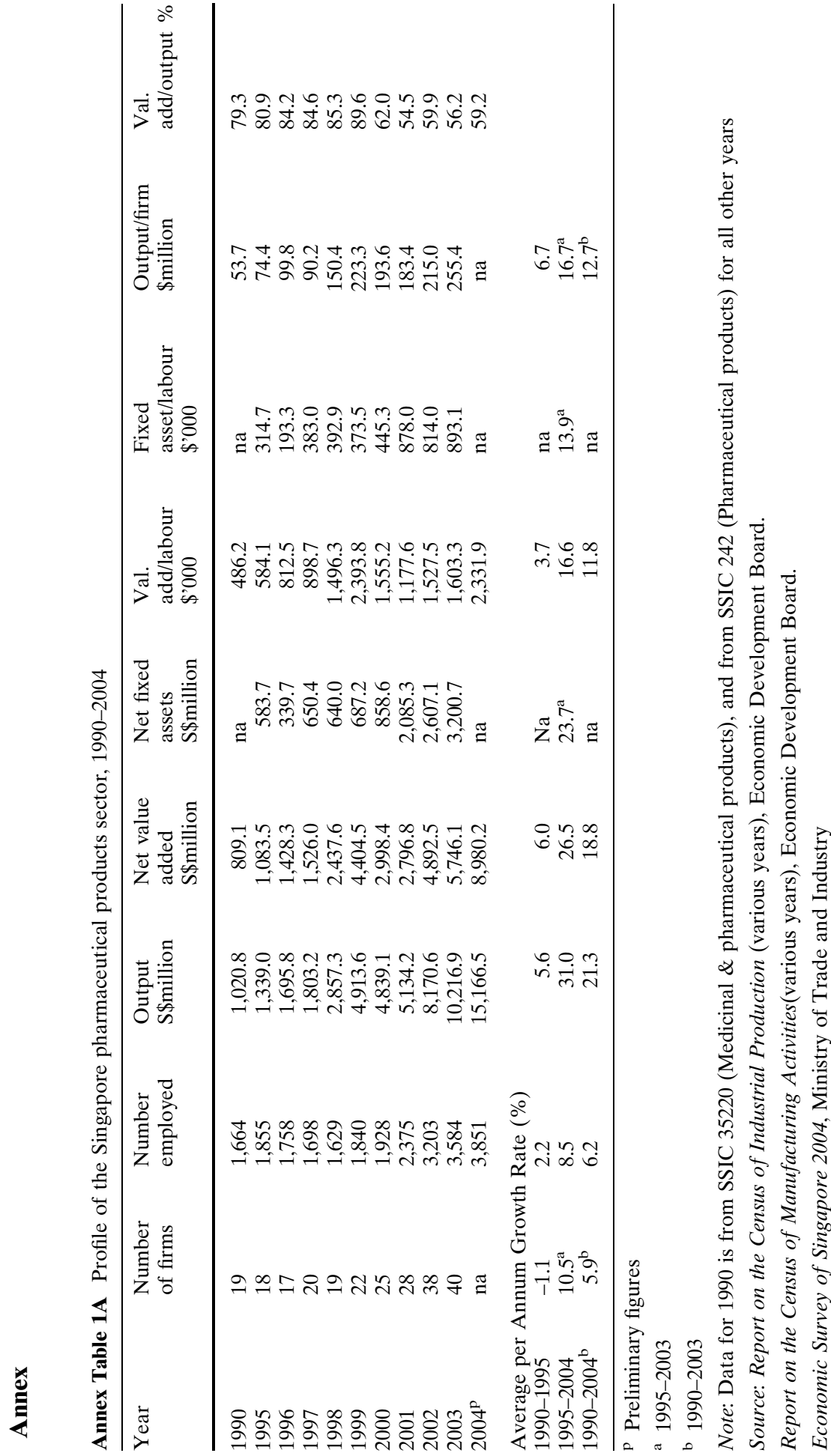




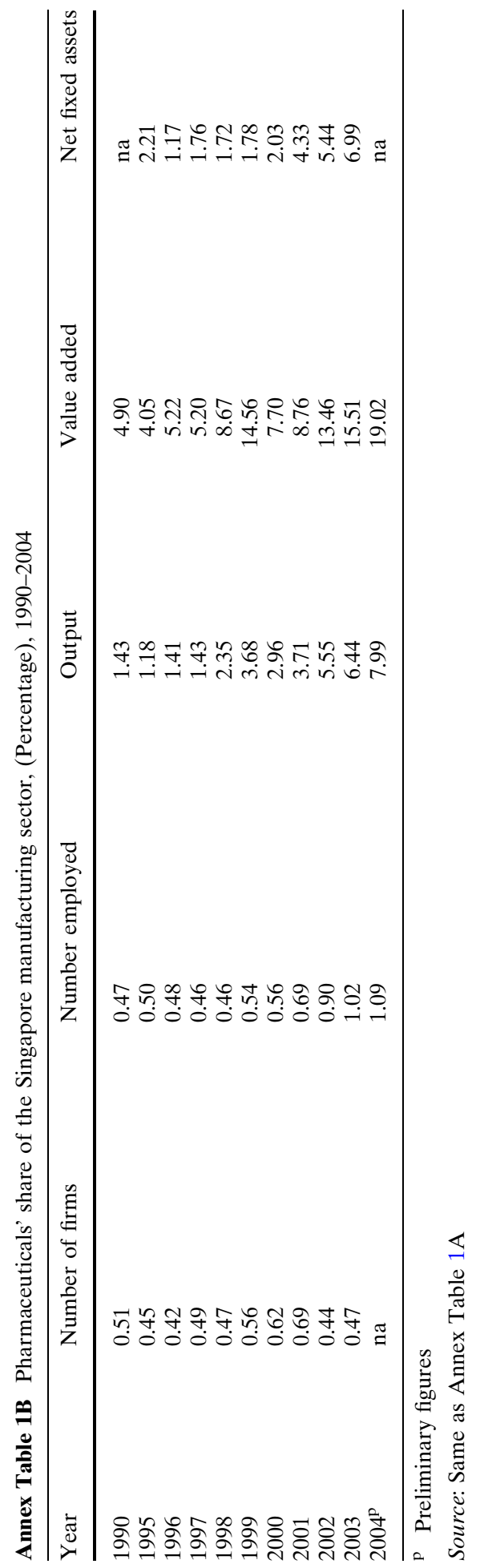




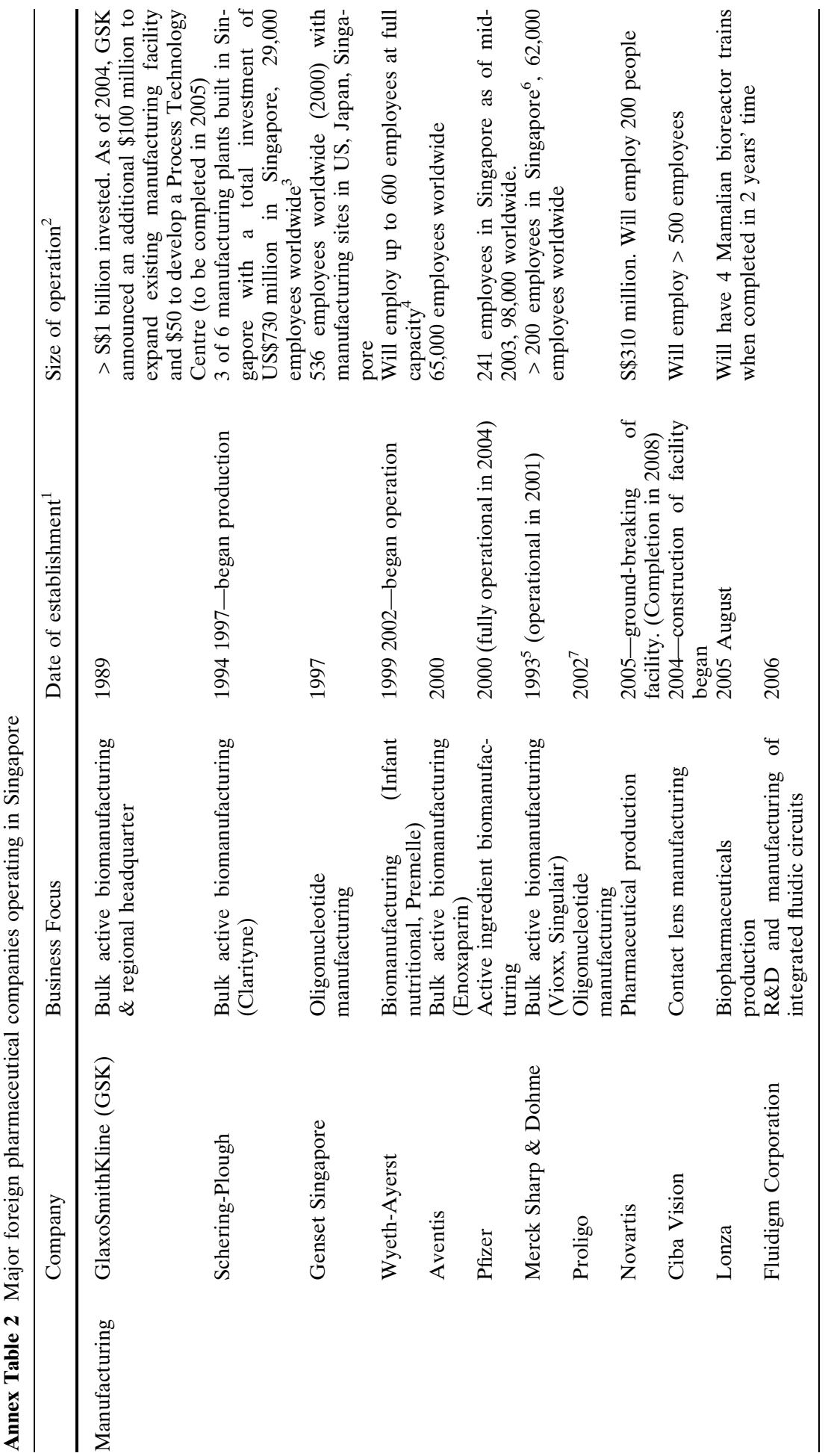




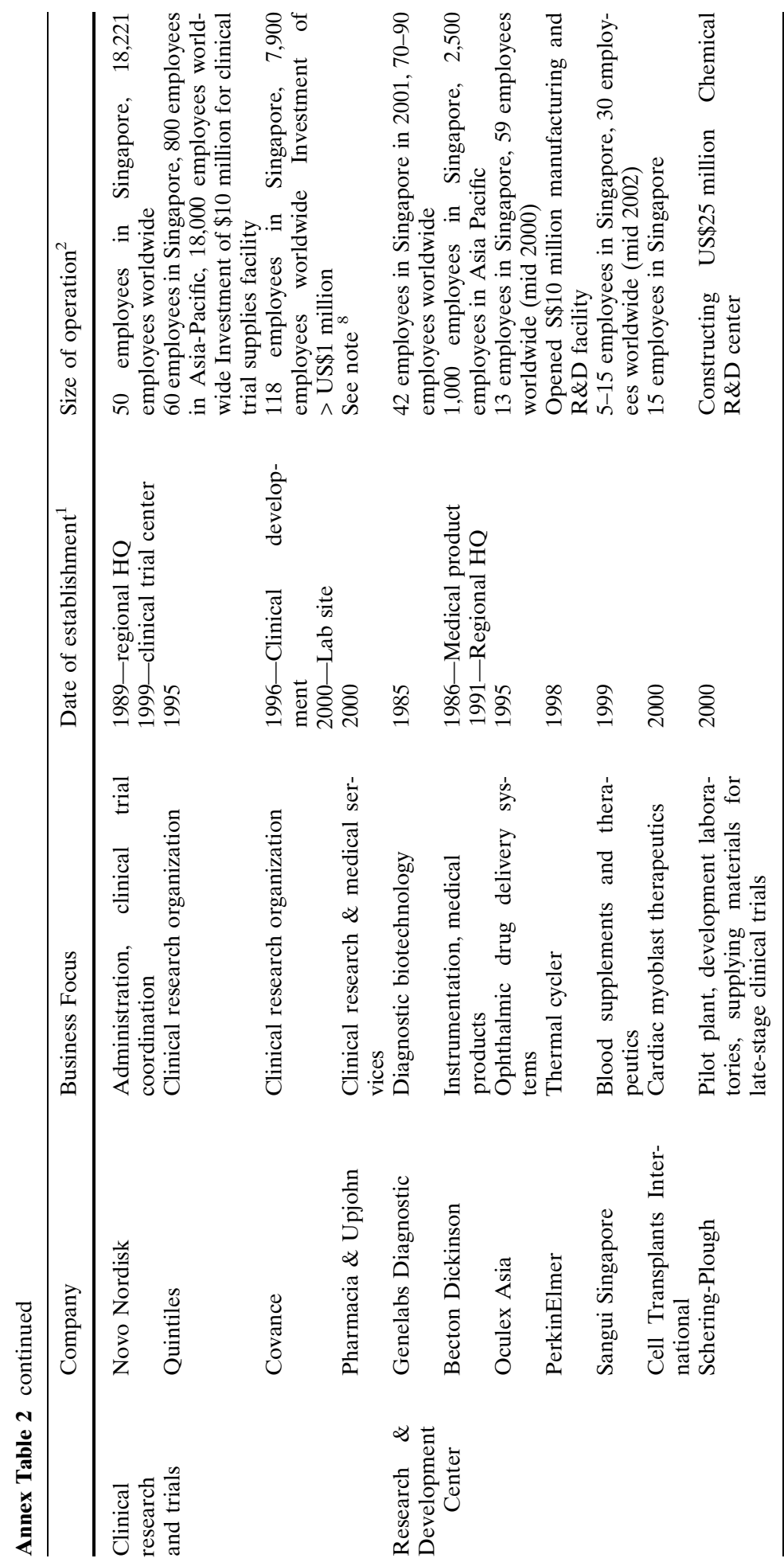




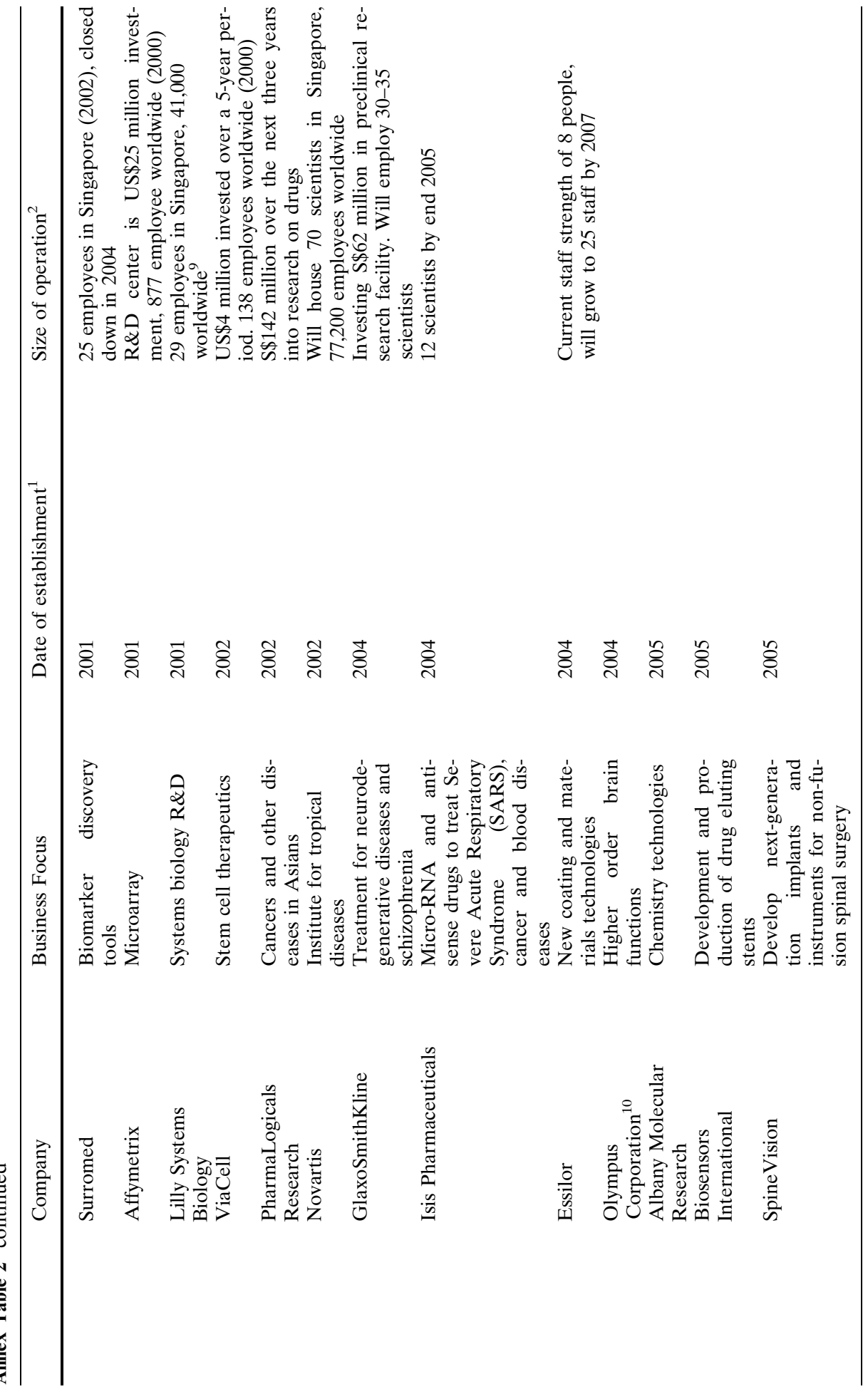

望 Springer 


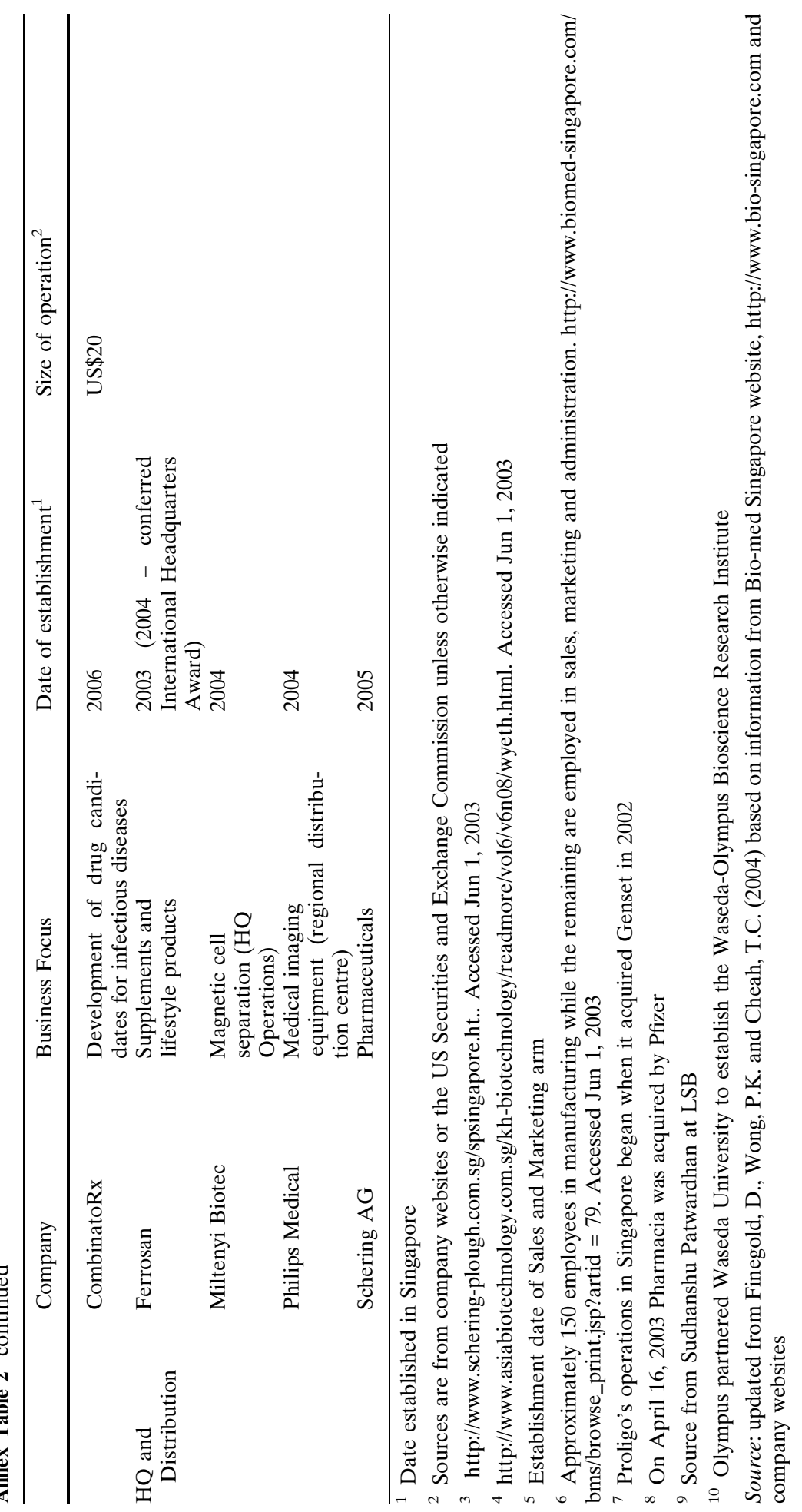




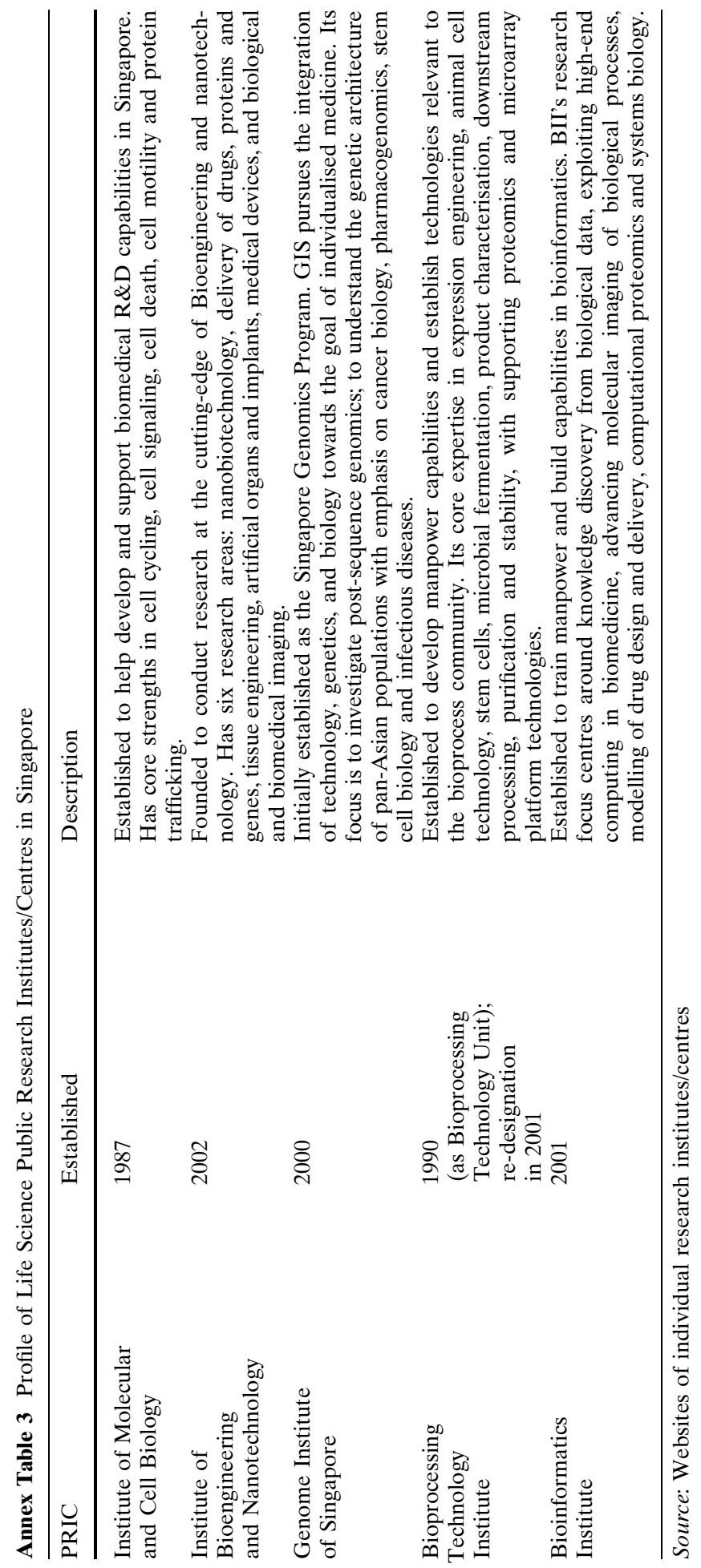




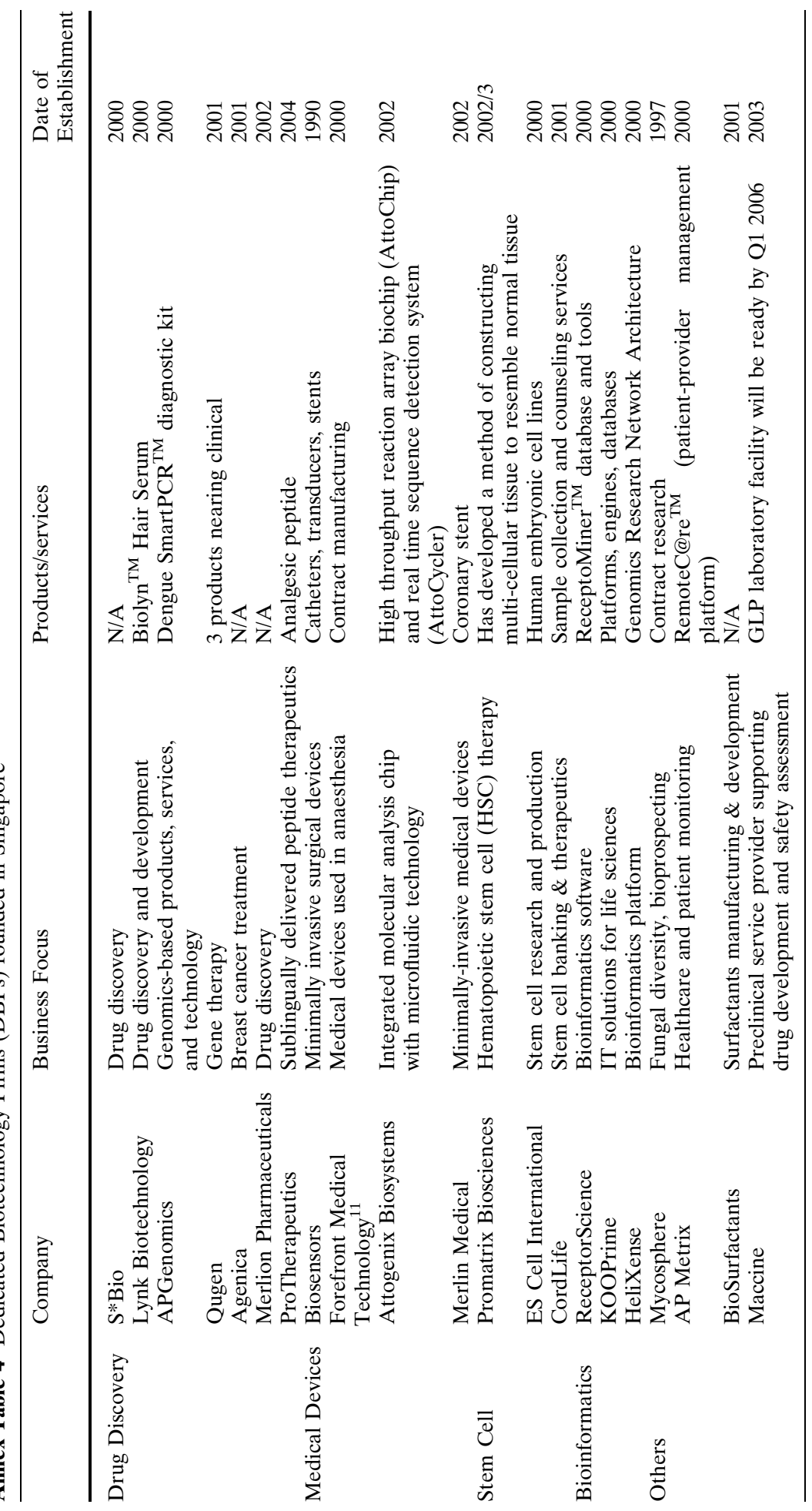




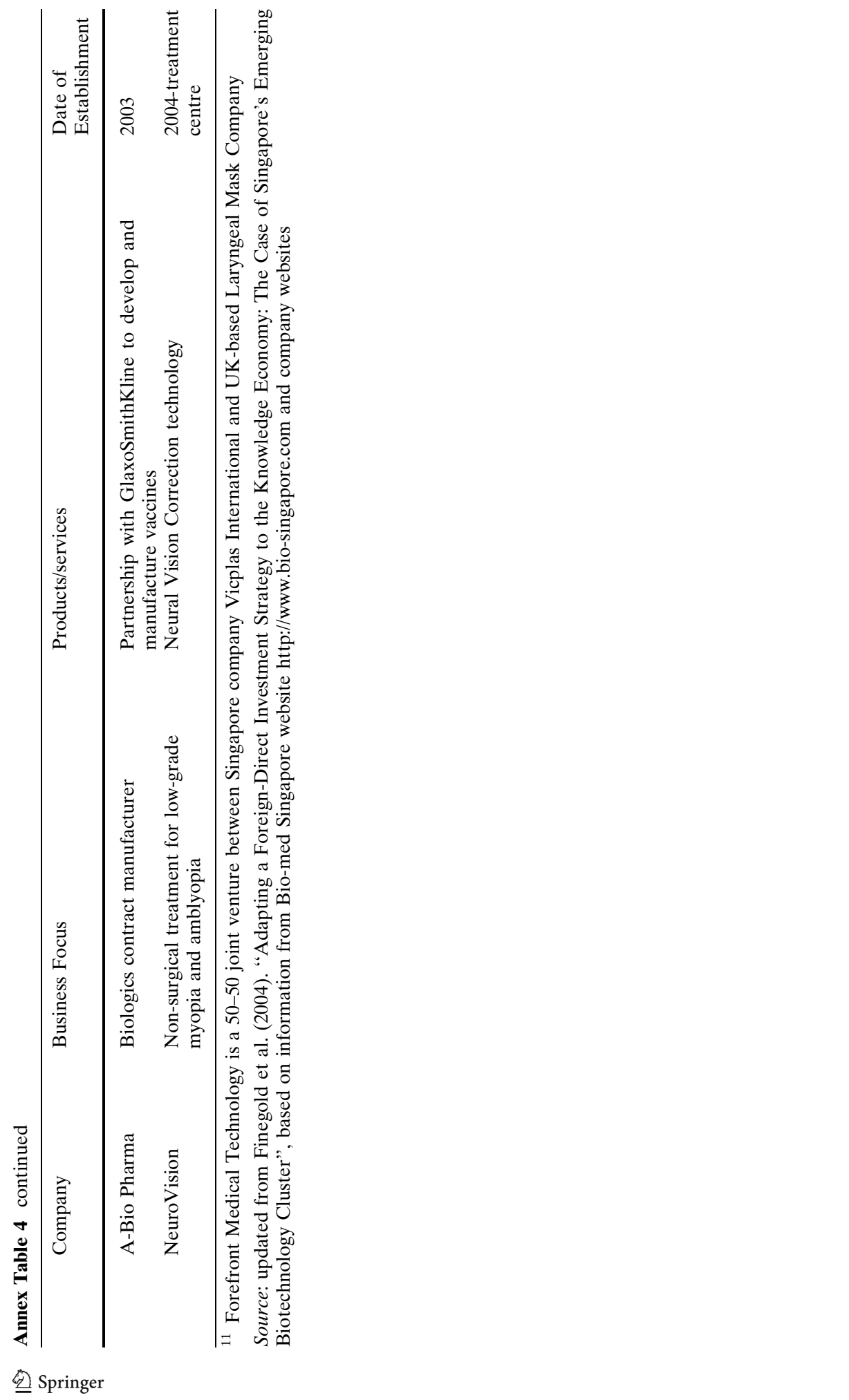


Annex Table 5 Milestones in the Singapore Biomedical Sector

\begin{tabular}{|c|c|}
\hline 1987 & Setup of Institute of Molecular and Cell Biology (IMCB) \\
\hline 1995 & Setup of Bioprocessing Technology Institute (BTI) \\
\hline \multirow[t]{2}{*}{1998} & Setup of Centre for Drug Evaluation (CDE) \\
\hline & World-renowned Johns Hopkins University setup Johns Hopkins Singapore \\
\hline 1999 & Setup of Genetics Modification Advisory Committee (GMAC) \\
\hline \multirow[t]{9}{*}{2000} & Singapore became first Asian country to accede to the Pharmaceutical Inspection \\
\hline & Co-operation Scheme, Geneva \\
\hline & Setup of Genomics Institute of Singapore (GIS) \\
\hline & Setup of Life Sciences Ministerial Committee \\
\hline & Agency for Science, Technology and Research (A*STAR) established Biomedical \\
\hline & Research Council (BMRC) \\
\hline & Setup of Bioethics Advisory Committee (BAC) \\
\hline & Setup of Biomedical Sciences International Advisory Council (IAC) \\
\hline & Tuas Biomedical Park \\
\hline \multirow[t]{6}{*}{2001} & Formation of Biomedical Sciences Manpower Advisory Committee (BMAC) \\
\hline & Lilly setup Biology R\&D Centre focused on systems biology \\
\hline & Setup of Bioinformatics Institute (BII) \\
\hline & Groundbreaking of Biopolis \\
\hline & Setup Norvatis Institute for Tropical Diseases (NITD) in Singapore \\
\hline & BioMedical Sciences Innovate 'N Create Scheme \\
\hline \multirow[t]{5}{*}{2002} & Setup of Singapore Tissue Network (STN) \\
\hline & Merger of Laboratories for Information Technology and Institute for Communications \\
\hline & Research to form Institute for Infocomm Research (IIR) \\
\hline & Setup of Institute of Bioengineering and Nanotechnology (IBN) \\
\hline & Setup of Cancer Syndicate \\
\hline \multirow[t]{4}{*}{2003} & Centre for Natural Product Research privatized to become MerLion Pharmaceuticals \\
\hline & Launch of SingaporeMedicine \\
\hline & Launch of Proof of Concept (POC) Scheme \\
\hline & Opening of Biopolis \\
\hline \multirow[t]{10}{*}{2004} & Setup of The Regional Emerging Diseases Intervention (REDI) Centre \\
\hline & Setup of The Centre for Molecular Medicine (CMM) \\
\hline & Setup of Chemical Process Technology Centre (CPTC) \\
\hline & Opening of Swiss House \\
\hline & Launch of Singapore Researchers Database \\
\hline & Passage of the Human Cloning And Other Prohibited Practices Bill \\
\hline & Setup of GSK Corporate R\&D Centre \\
\hline & Launch of BioSingapore \\
\hline & $\begin{array}{l}\text { The National Advisory Committee for Laboratory Animal Research (NACLAR) } \\
\text { announced amendments to the Animals and Birds Act to prevent inhumane treatment } \\
\text { of lab animals }\end{array}$ \\
\hline & $\begin{array}{l}\text { Bioethics Advisory Committee (BAC) announced the publication of l"Research } \\
\text { involving Human Subjects: Guidelines for IRBsl" }\end{array}$ \\
\hline \multirow[t]{2}{*}{2005} & Launch of Medtech Concept \\
\hline & Launch of Medtech Local Supplier Group \\
\hline
\end{tabular}

Source:http://www.biomed-singapore.com/bms/sg/en_uk/index/about_biomedical_sciences/milestones.html

BMSG, BIO*ONE AND BMRC. (2006). "Biomedical Sciences Industry Maintained Growth Momentum In 2005", downloaded from: http://www.biomed-singapore.com/bms/sg/en_uk/index/ newsroom/pressrelease/year_2006/2006_biomedical_sciences.html 
Annex Table 6 Profile of NUS biomedical-related spin-off companies

\begin{tabular}{|c|c|c|c|c|}
\hline $\begin{array}{l}\text { Incorporated } \\
\text { Date }\end{array}$ & Name & Nature of business & $\begin{array}{l}\text { Founders } \\
\text { fromNUS }\end{array}$ & Department \\
\hline 1995 & $\begin{array}{l}\text { Allegro Science } \\
\text { Pte Ltd }\end{array}$ & $\begin{array}{l}\text { Produce and market } \\
\text { sequencing and } \\
\text { DNA labeling kits }\end{array}$ & $\begin{array}{l}\text { Dr Victor Wong } \\
\text { Wong Thi }\end{array}$ & Biology \\
\hline 1999 & $\begin{array}{l}\text { BioMedical } \\
\text { Research } \\
\text { and Support } \\
\text { Services }\end{array}$ & $\begin{array}{l}\text { Biological evaluation } \\
\text { of medical devices } \\
\text { and equipment }\end{array}$ & $\begin{array}{l}\text { Assoc Prof } \\
\text { Eugene Khor }\end{array}$ & Chemistry \\
\hline 2001 & $\begin{array}{l}\text { BioNutra } \\
\text { International } \\
\text { Pte Ltd }\end{array}$ & $\begin{array}{l}\text { Nutraceuticals and } \\
\text { biopharmaceuticals }\end{array}$ & $\begin{array}{l}\text { Mr Victor Ong } \\
\text { Yek Cheng, } \\
\text { Assoc Prof } \\
\text { Paul Heng, } \\
\text { Assoc Prof } \\
\text { Yong Eu Leong }\end{array}$ & Pharmacy \\
\hline 2002 & $\begin{array}{l}\text { Chiral Sciences \& } \\
\text { Technologies } \\
\text { Pte Ltd }\end{array}$ & $\begin{array}{l}\text { Pharmaceutical and } \\
\text { biopharmaceutical } \\
\text { intermediates and } \\
\text { fine chemicals }\end{array}$ & $\begin{array}{l}\text { Prof Ching Chi Ban, } \\
\text { Assoc Prof Ng } \\
\text { Siu Choon }\end{array}$ & Chemistry \\
\hline 2000 & ES Cell Pte Ltd & $\begin{array}{l}\text { Embryonic stem } \\
\text { cell technology }\end{array}$ & $\begin{array}{l}\text { Scientific Advisor, } \\
\text { Dr Ariff Bongso }\end{array}$ & $\begin{array}{l}\text { Medicine- } \\
\text { Obstetrics and } \\
\text { Gynaecology }\end{array}$ \\
\hline 2000 & $\begin{array}{l}\text { KOO Prime } \\
\text { Pte Ltd }\end{array}$ & $\begin{array}{l}\text { IT solutions provider } \\
\text { for the life sciences, } \\
\text { bio-mining software }\end{array}$ & Mr Lim Teck Sin & $\begin{array}{l}\text { Center for } \\
\text { Natural Product } \\
\text { Research }\end{array}$ \\
\hline 2000 & $\begin{array}{l}\text { LYNK Biotech } \\
\text { Pte Ltd }\end{array}$ & $\begin{array}{l}\text { Drug development } \\
\text { technology }\end{array}$ & $\begin{array}{l}\text { Assoc Prof Lee } \\
\text { Chee Wee }\end{array}$ & $\begin{array}{l}\text { Medicine- } \\
\text { Physiology }\end{array}$ \\
\hline 1997 & $\begin{array}{l}\text { Oribiotech } \\
\text { Pte Ltd }\end{array}$ & Develop tumor markers. & Dr Ng Wee Chit & Medicine \\
\hline 2003 & $\begin{array}{l}\text { OsteoPore } \\
\text { Pte Ltd }\end{array}$ & $\begin{array}{l}\text { Biodegradable Bone } \\
\text { Scaffold }\end{array}$ & $\begin{array}{l}\text { Prof Teo Swee Hin } \\
\text { Dr. Dietmar } \\
\text { Hutmacher }\end{array}$ & Bio-engineering \\
\hline 2003 & $\begin{array}{l}\text { Quantagen } \\
\text { Pte Ltd }\end{array}$ & $\begin{array}{l}\text { Label-free detection } \\
\text { technology for } \\
\text { gene analysis }\end{array}$ & Prof Casey Chan & Orthopaedic \\
\hline 2004 & ProTherapeutics & $\begin{array}{l}\text { Sublingual delivery } \\
\text { of peptide } \\
\text { therapeutics }\end{array}$ & & Medicine \\
\hline
\end{tabular}

\section{References}

Agency for Science, Technology \& Research (A*STAR). (various years). National Survey of R\&D in Singapore. Singapore: A*STAR.

A*STAR (2005). "Singapore's Biomedical Sciences Industry Recorded Exceptional 33\% Growth in Manufacturing Output For 2004", http://www.a-star.edu.sg/astar/biomed/action/pressrelease_details.do?id $=0 \mathrm{fb} 4 \mathrm{e} 42369 \mathrm{Mm}$.

Allen, K.,Wong, P.K. (2003). Technology spin-offs from Pacific Rim Universities: Entrepreneurial context and economic impact, paper presented at the 23rd Babson-Kauffman Entrepreneurship Research Conference, June 3-5, 2003.

Biomed-Singapore (2003) (http://www.biomed-singapore.com/bms/gi_mc.jsp)

Bioprocessing Technology Institute website, http://www.bti.a-star.edu.sg/

Bioinformatics Institute website, http://www.bii.a-star.edu.sg/

Casper, S. (2003). Commercializing science in Europe: The Cambridge biotechnology cluster. European Planning Studies, 11, 825-823.

Chang, A. L. (2001). Maintaining S'pore's lead in stem-cell race. The Straits Times, Sept 5. 
Cooke, P. (2003). The evolution of biotechnology in three continents: Schumpeterian or Penrosian? European Planning Studies, 11, 757-763.

Cooke, P. (2004). The accelerating evolution of biotechnology clusters. European Planning Studies, $12,915-920$.

EDB (various years) Report on the census of industrial production. Singapore: EDB.

EDB (various years) Report on the census of manufacturing activities. Singapore: EDB.

Etzkowitz, H., Webster, A., Gebhardt, C., \& Terra, B. R. C. (2000). The future of the university and the university of the future: Evolution of ivory tower to entrepreneurial paradigm. Research Policy, 29, 313-330.

Feldman, M. P., \& d Francis, J. L. (2003). Fortune Favors the Prepared Region: The case of entrepreneurship and the capitol region biotechnology cluster. European Planning Studies 11, 765-787.

Finegold, D., Wong, P. K., \& Cheah, T. C. (2004). Adapting a foreign direct investment strategy to the knowledge economy: The case of Singapore's emerging biotechnology cluster. European Planning Studies, 12(7), 921-941.

Genome Institute of Singapore website, http://www.gis.a-star.edu.sg/

Institute of Bioengineering and Nanotechnology website, http://www.ibn.a-star.edu.sg/

Institute of Molecular and Cell Biology website, http://www.imcb.a-star.edu.sg/

Lehrer, M., \& Asakawa, K. (2004). Rethinking the public sector: idiosyncrasies of biotechnology commercialization as motors of national R\&D reform in Germany and Japan. Research Policy, 33, 921-938.

National Science \& Technology Board. (various years). National Survey of R\&D in Singapore. Singapore: NSTB.

National University of Singapore (NUS). (2004). NUS Annual Research Report 2003-2004. Singapore: National University of Singapore.

NUS. (various issues). Knowledge Enterprise Online, downloaded from http://www.newshub.nus.edu.sg/

Owen-Smith, J., Riccaboni, M., Pammolli, F., \& Powell W. W. (2005). A comparison of US and European University-industry Relations in the Life Sciences. Management Science, 48, $24-43$.

Prevezer, M. (2001). Ingredients in the early development of the U.S. biotechnology industry. Small Business Economics, 17, 17-29.

The Times Higher Education Supplement website, http://www.thes.co.uk/statistics/international_comparisons/2004/main.aspx

Traufetter, G. (2005). Biotech in Singapore: A treasure island for Elite researchers. Spiegel Online http://www.service.spiegel.de/cache/international/spiegel/0,1518,349122,00.html

Tsui-Auch, L. S. (2004). Bureaucratic rationality and nodal agency in a developmental state: The case of state-led biotechnology development in Singapore. International Sociology, 19(4), 451477.

United States Patent and Trademark Office website: http://www.uspto.gov/patft/index.html

Wong, P.K. (2005). From technology adopter to innovator: The dynamics of change in the National System of Innovation in Singapore. In: C. Edquist, \& L. Hommen (Eds.), Small economy innovation systems: Comparing globalization, change and policy in Asia and Europe, Elgar (forthcoming).

Wong, P. K. (2002). Globalization of American, European and Japanese Production Networks and The Growth of Singapore's Electronics Industry. International Journal of Technology Management, 24(7/8), 843-869.

Wong, P.K. (2001). Leveraging Multinational Corporations, Fostering Technopreneurship: The Changing Role of S\&T Policy in Singapore, International Journal of Technology Management, $22(5 / 6), 539-567$.

Zucker L., \& Darby M. (1996). Star scientists and institutional transformation: Patterns of invention and innovation in the formation of the biotechnology industry. Proceedings of the National Academy of Sciences USA, 93, 12709-12716. 